\title{
A Contract Theory Approach to Special and Differential Treatment and the WTO
}

\section{Conceptual Paper}

\begin{abstract}
Purpose

This paper is prompted by the dissatisfaction of developing countries regarding the grant of special and differential treatment (SDT) under the legal framework of the World Trade Organisation (WTO). As a result of such dissatisfaction, the Doha Round of multilateral trade negotiations explicitly called for a review of such treatment with a view to making it more precise, effective and operational. This mandate has not yet been met to the satisfaction of many developing countries. This paper aims to provide an alternative way of examining and evaluating the contestation which exists regarding SDT in the WTO.
\end{abstract}

\section{Design/methodology/approach}

This paper employs the conceptual framework provided by economic contract theory and in particular, the concept of the incomplete contract to provide a scaffold for analysing SDT. This approach is intended to offer insights beyond those elucidated so far in the literature on the topic.

\section{Findings}

This paper, by employing an economic contract theory approach, finds that SDT is constructed as an incomplete contract. Furthermore, the suboptimal outcomes associated with incomplete contracts are apparent in the constitution of SDT. This finding is useful in both an evaluative and programmatic sense; providing us with an alternative entry point to explain some of the shortcomings with SDT as well as garnering us with a useful conceptual tool to think upon how SDT can be improved.

\section{Originality/value}

The paper contributes to the literature on SDT within the WTO in particular as well as differential treatment in international law in general. Drawing on literature on the WTO as an 
incomplete contract, the paper provides an original frame for analyzing SDT and draws attention, in particular, to the utility of economic contract theory as a programmatic and evaluative frame for SDT and differential treatment more generally.

\section{Introduction}

International law has long grappled with how to structure legal obligations in a way that takes account of developing country needs and circumstances (Rajamani, 2006). Within the context of the climate change regime for example, the issue of whether equal obligations are appropriate given developing countries' different historical contributions to climate change has been much contested (McGee and Steffek, 2016, p. 51). Similarly, in the multilateral trade regime, while developing countries were initially subject to the same rules as their developed counterparts, a shift away from such obligational equality occurred in the early years of the General Agreement on Tariffs and Trade (GATT). This was in part a response to equity-related concerns (see generally Lamp, 2015). The practice of providing for a differential legal regime in favour of developing countries continued into the World Trade Organisation (WTO) with such treatment known as special and differential treatment (SDT). While there is no universally recognised definition for SDT, it is generally understood to refer to provisions such as those which permit developing countries to offer, 'less than full reciprocity' in tariff liberalisation negotiations, measures inserted into the legal texts of the WTO to assist developing countries to address certain development, financial and trade needs as well as adjust to the rigours of the WTO legal system (WTO, 2016). SDT is only available to developing countries and least-developed countries (LDCs). ${ }^{\mathrm{i}}$

Over 170 provisions of SDT currently exist within the WTO legal framework (WTO, 2016) and it is currently conceived of as a central component of ongoing negotiations in a range of areas. ${ }^{\text {ii }}$ (Doctrinal) legal analysis has done much to elucidate upon the nature of the WTO legal contract and the place of SDT therein. Much of this literature has been evaluative; finding that developing countries have incurred significant problems in operationalising the SDT component of the WTO contract.

In this analysis, I seek to enrich our understanding of SDT and its operationalisation within the WTO. I use a different lens to that traditionally adopted by legal scholars and instead adopt the analytical lens provided by economic contract theory. Economic contract theory 
illuminates the difficulties contracting parties face in designing a contract which is both optimal ex ante and one which is optimal ex post (Scott and Stephan, 2006, p. 61). These difficulties stem in part from the possibility that some unforeseen event - contingency - may arise during the performance stage of the contract (Scott and Stephan, 2006, p. 61). Accordingly, it is nigh on impossible for parties to design a pareto optimal complete contingent contract which assigns, 'risks, rights and responsibilities in every possible state of the world' (van Aaken, 2009, p. 515). Parties to a contract may instead form a contract containing certain gaps; in essence, they may reach what is referred to as an incomplete contract.

Incomplete contracts are not inherently irrational. Trade agreements are in general, 'highly incomplete contract(s)' (WTO, 2009a, p. 28). This is because in a 'dynamic, non-stationary world it is both rational and efficient for contracting parties to deliberately leave contractual gaps in a trade agreement and to refrain from writing a fully contingent contract' (WTO, 2007, p. 117). Contractual incompleteness does, however, leave, 'ample room for ambiguity, controversial interpretations, misunderstanding, and opportunism' (WTO, 2007, p. 98). Where contracts are incomplete, a number of shortcomings may arise such as too much discretion being granted to one or other party, ambiguous or vague phrases, 'resulting from poorly described contingencies and their outcomes' and finally, a contract which is too rigid (Gantz and Schropp, 2009, p. 170).

The WTO legal compact has been recognised as an incomplete contract (Shropp, 2009). Such contractual incompleteness is identifiable across a range of areas. The Dispute Settlement Understanding (DSU), for example, contains a significant gap in that it does not set out the burden of proof applicable to parties to a dispute (Hoekman and Mavroidis, 2012). No formal rule exists under the GATT as to whether a state may prevent the importation of a good due to the way in which it has been produced if the process or production method does not affect the final product (Trachtman, 2007, p. 645). ${ }^{\text {iii }}$ Similarly many of the GATT's core provisions are vaguely phrased such that, the 'actual ambit of the agreement is (...) left largely to be determined by adjudicating bodies' (Horn, Maggi and Staiger, 2006, p. 1).

There is hence a wealth of literature utilizing economic contract theory as powerful analytical frame to better understand and explain the constitution of WTO law (Schropp, 2009, chapter one). No comprehensive analysis has yet, however, been undertaken applying this frame to SDT. In this article, I posit that economic contract theory is useful for enriching our 
understanding of SDT. I find that SDT is very much constructed as an incomplete contract and that the suboptimal outcomes associated with incomplete contracts are apparent in the constitution of SDT. This is useful in both an evaluative and programmatic sense; providing us with an alternative entry point to explain some of the shortcomings with SDT as well as allowing us to think upon how SDT can be improved.

This study is particularly apposite due to the appearance of a new type of SDT offered under the recently entered into force WTO Agreement on Trade Facilitation (TFA). This agreement has been heralded as marking a sea change for SDT; for the first time in WTO legal history, the legal obligations of developing and least developed countries are tied to the receipt of implementation assistance. The innovation of the TFA has encouraged some commentators to posit that it could provide, 'a model for future WTO Agreements' (Eliason, 2015, p. 662). In this article, I seek to interrogate whether the TFA is able to offer a strengthened and effective approach to SDT that addresses the needs of developing and LDC Members.

In the first section of this article I set out the conceptual and theoretical background to my investigation. SDT is introduced and its place within the legal framework of the WTO is elucidated upon. This is followed by a short introduction to economic contract theory with particular attention paid to the frame of the incomplete contract. I then apply the analytical framework of economic contract theory to a number of provisions of SDT, finding that the examined provisions of SDT are contractually incomplete and suffer from the deficiencies noted above. In section two, the analysis turns to the TFA with the lessons of contract theory once again applied to deepen our understanding of the SDT provisions therein. In this section, I seek to address whether the TFA is capable of offering a new model of more complete contractual arrangements addressing the differential needs of developing and least developed countries. I find that the TFA offers a much improved balance between ex ante commitment and ex post flexibility than that available under the Uruguay Round agreements. In the final section, I conclude by drawing attention to SDT as a core component of the 'developmentification' of the WTO. Given this and going forward, it is clear that much benefit would be derived from employing contract theory as a programmatic tool which can operate alongside more traditional forms of legal analysis to both warn of and remedy obligational defects in the operationalization of differential treatment. 


\section{Section One - The operation of Special and Differential Treatment as an Incomplete} Contract

\section{SDT in a nutshell}

Differential treatment in favour of developing countries is commonplace within the international legal regime (Cullet, 1999). Within the multilateral trade regime, SDT comprises a range of provisions under the Agreements and Decisions which together comprise the multilateral trade regime (WTO, 2016). It is inherently linked to the 'development dimension', of the WTO though the precise nature of this connection is contested. ${ }^{\mathrm{v}}$ Developing countries have long expressed two concerns regarding SDT; that its encompassing provisions have not met their needs and that SDT's lack of efficacy stems from the nature of its legal construction;

The challenge was that the S\&D (SDT) regime had not assisted developing countries, in particular, LDCs, SVEs, and low-income developing countries, to participate effectively in the multilateral trading system (MTS), mainly because most of the S\&D provisions were couched in hortatory and best endeavour language and had not been fully operationalized. ${ }^{\mathrm{vi}}$

Disappointment with SDT prompted developing countries to request that its encompassing provisions be reviewed under the auspices of the Doha Round of multilateral trade negotiations. The mandate for this review was included under paragraph 44 of the 2001 Doha Declaration. Pursuant to this, Members agreed that, all special and differential treatment provisions shall be reviewed with a view to strengthening them and making them more precise, effective and operational (emphasis added). ${ }^{\text {vii }}$

Given the link, however contested, between SDT and development, questions as to SDT's effectiveness inevitably bring to the fore, 'the credibility of the WTO system' (WTO, 2015). ${ }^{\text {viii }}$ Despite this, the paragraph 44 mandate has not yet been fully met (South Centre, $2017)^{\text {ix }}$. In part, the failure to meet this mandate stems from a lack of agreement between Members as to the problem the paragraph 44 review mandate is trying to address. Indeed, the representative of the EU in a recent meeting of the WTO Committee on Trade and Development, questioned in respect to the paragraph 44 review of SDT, 'Are we trying to tackle real problems?' (WTO, 2015a) ${ }^{\mathrm{x}}$ 
The lessons of economic contract theory allow us to better position and understand constitution of SDT within the legal order of the WTO itself as well as conceptualise the 'problem' the paragraph 44 review mandate is trying to address. As we know, the WTO is generally conceived of as an incomplete contract, containing gaps which leave, 'ample room for ambiguity, controversial interpretations, misunderstanding, and opportunism' (WTO, 2007, p. 98). Many of the provisions of SDT are similarly incomplete. This is evident from the very wording of the paragraph 44 review mandate with its attendant focus upon making SDT more precise, effective and operational.

We can therefore conceptualise the paragraph 44 review mandate as an attempt to address the contractual incompleteness of SDT. Contract theory may therefore be useful in an evaluative sense to enrich our understanding of how SDT is incomplete. In the next subsection, I provide some useful background on economic contract theory while at the same time applying it to SDT in order to elaborate more fully on how SDT is incomplete. This is accompanied by commentary on the implications of such incompleteness for the operationalisation of SDT.

\section{Contract theory and asymmetric information, vagueness and ambiguity}

Contract theory teaches us that for any mutually beneficial collective activity, a separation may exist between the costs of an activity for which each party is responsible on an individual basis, and the benefits of the activity in question which are collective and which the parties hence share (Scott and Stephan, 2006, p. 18). As a consequence, each party may have much to gain from opting out of their commitments as they will still share in the collective benefits (Scott and Stephan, 2006, p. 18). However, if everyone was to do this, the anticipated benefits from the contract would erode. This tension between collective and individual benefit creates what is known as a moral hazard (Scott and Stephan, 2006).

Situations of moral hazard can arise under situations of asymmetric information during the performance stage of the contract. This is because informational asymmetries may present difficulties in monitoring contractual performance (Scott and Stephan, 2006, pp. 71 - 72). If the party to whom an obligation is owed incurs difficulties in monitoring contractual performance, then the contracting party owing the obligation may effectively abuse this position and attempt to escape their commitments (Scott and Stephan, 2006, pp. 71 - 72). Devices such as 'contractual mechanisms that induce revelation of private information with formally enforceable rules' (Scott and Stephan, 2006, p 76) may be required. 
Informational asymmetries abound under both the WTO Agreements and indeed SDT. A prominent example may be found in the Agreement on Sanitary and Phytosanitary measures (SPS). Article 10.1 SPS mandates that, 'in the preparation and application of sanitary or phytosanitary measures, members shall take account of the special needs of developing country members.' This measure clearly requires developed countries to, 'take account' of developing country needs. However, in the run up to the launch of the Doha Round, developing countries noted that their 'special needs' had only rarely been considered (WTO, 2000, para. 4). In 2002, it was further noted that there was only limited information available on whether the obligation under Article 10.1 had actually been met (WTO, 2002a, pp. 21 22; Author, 2012, p. 228).

Using the lens of contract theory, one difficulty arising from a provision such as Article 10.1 SPS is the ability to observe whether a party has performed their obligation under it. The party who possesses information as to whether developing country needs have indeed been taken into account is the importing - developed - country (WTO, 2002a, pp 21 - 22. The developing exporting country which the provision is meant to favour thus faces significant difficulties in observing whether their needs have been taken into account since no procedure for assessing performance was specified under the Agreement.

In regard to the above concerns, the SPS Committee has taken steps improve the operation of Article 10.1 SPS. Following on from proposals by Egypt (WTO, 2002b) and Canada (WTO, 2002c) a procedure was adopted to enhance the transparency of SPS notifications in favour of developing country Members (WTO, 2004). Under this procedure, and following notification of an SPS measure, the developing exporting country would have the opportunity to contact the importing country to discuss any concerns it may have regarding the proposed measure. Upon receipt of such a request, the importing country will contact the exporting country and enter into discussions to consider how best the special needs of the exporting member may be taken into account. This could include a change in the measure at issue to be applied on an MFN basis or the provision of technical assistance to the exporting developing country. SDT may also be applied in relation to the measure although such treatment would have to be available to all developing countries on a MFN basis (WTO, 2004, p. 2). Finally, when a measure was adopted, the importing member was required to amend its original notification to reflect this (WTO, 2004, p. 3). 
In 2009, the procedure was revised to incorporate Member comments as to its efficacy (WTO, 2009b). This new procedure introduced a further transparency requirement whereby '[w]hen an importing Member decides on whether and how special and differential treatment may be provided in response to a specific request, that Member should inform the SPS Committee.' The report is mandated to provide a summary of whether SDT was provided and if not, why not (WTO, 2009b, p. 3). ${ }^{\mathrm{xi}}$

At a broad level of generality, the construction of the above reporting mechanism comports with the lessons of economic theory which instructs that a contractual mechanism which induces or encourages the revelation of information can, if properly specified, 'eliminate the incentive to exploit party vulnerability while retaining the flexibility to adjust to new information arising during the course of contract performance' (Scott and Stephan, 2006, 79).

While, however, a reporting mechanism will be a suitable tool to employ where the substance of the obligation is agreed but observing performance is difficult, this may prove a suboptimal remedy where the obligation is not agreed upon. This is because what is reported may ultimately reflect a unilateral construction of the obligation. In essence, even if a party to whom an obligation is owed can observe the outcome, if that is all they can do, it is clear they cannot force the party owing the obligation to choose a particular action to meet the designated outcome (Salanié, 1997, p. 107). Accordingly, the G90 has proposed a number of improvements to the operationalisation of Article 10.1 SPS such as the introduction of a 'consultation mechanism' between exporting developing countries and importing developed countries (South Centre, 2015, p. 24).

Even if a review or consultation mechanism is in place ${ }^{\mathrm{xii}}$, contractual enforcement may also nevertheless be difficult where the obligation is written in ambiguous or vague language (Scott and Stephan, 2006, pp. 71 - 78). Gantz and Schropp (2009) give examples of 'catch-all phrases,' such as 'best effort,' 'gross inequity,' and 'serious injury' (p. 170) as coming within this category (see also Maggi and Staiger, 2008, p. 2), with the ambiguity of such terms presenting potential enforcement problems for the party relying on a vague provision (Gantz and Shropp, 2009, pp. 169 - 172; Scott and Stephan, 2006, p. 71). To resolve these contractual gaps, 'proxies' for performance may be required in order to assist in the task of enforcement (Scott and Stephan, 2006, p. 72). 
Many SDT provisions are phrased using vague terms. Examples include phrases such as the 'fullest extent possible' (GATT, Article XXXVII:1), 'special regard' (GATT, Article XXXVII:3 (b)), and, 'monitor, as appropriate' (Agreement on Agriculture, Article 16.2). In the absence of proxies, dispute settlement could of course be utilised to 'complete' the contract. There are, however, constitutional issues associated with the dispute settlement system 'gap filling' the incomplete WTO contract (Author, 2012). In addition, this strategy has not met with great success where developmental issues are concerned with Rolland (2012) articulating, '(w)here the wording of SDT clauses was ambiguous, adjudicators have often shied away from rigorous treaty interpretation exercises and have not attempted to develop tests, standards or methodologies that would be useful for future cases' (p. 139). Set in the context of a lack of routes to 'gap fill' such contractual completeness, the contractual frame allows us to identify the paragraph 44 mandate as a normal response to the presence of contractual incompleteness. This capacity of contract theory to normalise particular demands is further explored below in our elucidation on flexibility mechanisms.

\section{Contract theory and too much flexibility}

Economic contract theory teaches us that moral hazard may also arise from the use of flexible standards which permit subsequent ex post readjustment to take account of new situations (Scott and Stephan, 2006, p. 77). Flexible standards are not in themselves problematic. Indeed, where the transaction costs of agreeing to 'harder' terms are particularly high, parties to a contract may opt to allow the contracting parties ex post flexibility to adjust to deal with uncertain events (Scott and Stephan, 2006, pp 77 - 79). Moral hazard may, however, arise where, 'contracting parties (are given) too much discretion or manoeuvring space' which allows for 'opportunistic abuse' and reduces joint welfare (Gantz and Schropp, 2009, p. 170; see also $\mathrm{Wu}, 2015$, p. 108). In order to deal with this threat, devices which in effect 'police' the use of such flexibility may help to ameliorate this risk (Scott and Stephan, 2006, p. 79).

Flexibility is at the core of SDT with three forms of flexibility existent; flexibility of commitments, flexibility of action and flexibility regarding the use of policy instruments (WTO, 2001c, p. 7). The first class of flexibility essentially allows for a 'modulation' of commitments in very rough accordance with the development status of the member concerned (IISD, 2003, p. 1). The other two categories relating to flexibility of action and use of policy instruments includes provisions such as GATT Article XVIII: A which allows 
developing countries to modify and withdraw negotiated concessions subject to adherence with the procedure set out therein.

The Doha Round saw a series of requests by developing countries that they be given greater freedom to use certain tools otherwise prohibited. ${ }^{\text {xii }}$ There is significant debate as to the acceptability of certain flexibility mechanisms which developing countries claim are necessary due to the inappropriateness of 'traditional' flexibility mechanisms to meet their particular requirements. ${ }^{\text {xiv }}$ Opponents of the use by developing countries of tools such as TRIMS in essence fear that moral hazard could result if developing countries where given 'free reign' to utilise such instruments for developmental purposes (Hertel et. al, 2002, pp. $126-127) .{ }^{\mathrm{xv}}$ In response to the risk of moral hazard posed by overly flexible provisions 'in favour' of developing countries, a 'development policy review mechanism' has been proposed which could scrutinise the application or non-application of WTO law by developing countries (for example Trachtman, 2003, p. 20). One of the difficulties of creating such a mechanism is arbitrating upon what in constitutes permissible as well as impermissible behaviour.

Regardless of the practical difficulties of discerning the difference between permissible and impermissible behaviour, it is nevertheless the case that the WTO contract as a whole contains various ex post flexibility mechanisms. There are, for example, a number of escape clauses which, in principle, permit 'efficient breach' of the WTO contract in the event that unforeseen developments render compliance with the original contract inefficient or impossible (Mahlstein and Schropp, 2007, p. 2). Relatedly, some have posited that the rationale behind the introduction of escape clauses such as that found under Article XIX GATT is that at times, the political costs of compliance outweigh the benefits and so it may be optimal to allow non-performance (Schwartz and Sykes, 2002, p. 7).

Accordingly, while numerous developed countries have sought to depict requests for additional flexibility as outside the WTO system, flexibility is in fact a 'normal' part of the trade regime. It is, however, the case that contestation remains over the grant to developing and least developed countries of differentiated flexibility mechanisms. We can see this in a number of areas, not least in the contestation which surrounded the institution of a special safeguard mechanism (SSM) for agriculture. What arguably lay at the heart of contestation on the likes of the SSM was a fundamental difference of opinion in respect of the 'philosophical' purpose of such mechanisms (Wolfe, 2009, p. 518). Contract theory cannot 
answer such philosophical or indeed normative debates. What contract theory is useful for, however, is in elucidating on the interplay between the purpose of such flexibility and the need for some sort of mechanism to differentiate between permissible and opportunistic actions. Debates on the grant of flexibility mechanisms such as the SSM have not always given full consideration to this interplay and have therefore neglected the need to deliberate upon the principles informing such treatment, with a (premature) focus on designing a mechanism to operationalise it (see generally Wolfe, 2009). Indeed, more generally, there has been a tendency to transpose SDT as a set of 'tools' with little by way of philosophical reflection upon their conceptual underpinnings (WTO, 1995, p. 4). We see this more clearly in our discussion of ex post regret below.

\section{Contract theory and Ex post regret}

Economic contract theory teaches us that problems may arise in respect of a contract where the language is too rigid. Such a contract may, 'wrongly prohibit(...) non-performance in situations where a complete contingent contract would mandate welfare-enhancing ex post adjustment' (Gantz and Schropp, 2009, p. 170). Accordingly, while the use of hard(er) contractual terms may allow for more 'credible' upfront commitments (van Aaken, 2009, p. 515) they may serve to create ex post regret amongst signatories once certain unanticipated contingencies have come into being (Mahlstein and Schropp, 2007, p. 170). While overly rigid provisions may be renegotiated, this is often costly and the parties involved will not necessarily share similar interests in renegotiation (Scott and Stephan, 2006, p. 77).

Of course, ex post regret may also be prevented by allowing parties flexibility in the implementation of their commitments. In this vein, during the negotiation of the Uruguay Round agreements, it was recognized that developing countries could incur performance difficulties in implementing their WTO commitments. Accordingly, a total of twenty transition periods across eight of the covered agreements were made available to developing and least developed countries (WTO, 2016, p. 5). These granted time bound exceptions from legal obligations although the vast majority of these have now elapsed.

The rationale for granting countries additional time to meet their WTO commitments was detailed in a Secretariat note as reflecting the, 'recognition that the process of implementation of WTO, and accompanying reforms, could give rise to transitional costs' (WTO, 2001c, p. 8) While transition periods may be utilized to support commitments made and grant countries 
space to meet political and administrative adjustment costs, it is also the case that granting countries 'breathing space' in respect of commitments which do not address their respective needs merely delays the inevitable rise of ex post regret. In this sense, transition periods were, 'no more than a temporary aberration from the norm derived from developed countries' practices' (Lamp, 2015, p. 766). The construction of 'delayed implementation' as a form of SDT inherent in the Uruguay Round hence did little to contribute to substantive, as opposed to procedural, differential treatment (Cullet, 1999, p. 552).

\section{Summations}

It is clear the shortcomings associated with incomplete contracts are apparent in the operation of SDT. The lens provided by economic contract theory helped illustrate the paragraph 44 mandate as a normal response to the contractual completeness. We were also able to identify flexibility as a normal part of the trade regime, despite the contestation that remains over the grant to developing and least developed countries of differentiated flexibility mechanisms. Economic contract theory was also used to articulate how overly rigid provisions can result in ex post regret with arbitrary transition periods doing little to guard against this. The possibility of ex post regret underlines the importance of the contract formation stage in that 'when setting the optimal level of protection for international entitlements, one must be careful what one wishes for ...' (Pauwelyn, 2006, p. 64).

Having evaluated through the lens of economic contract theory some of the deficiencies associated with what we may think of as 'traditional' SDT, we now turn to review the potential of the TFA as offering a new, and more effective form of SDT. In essence, does the TFA suffer from the same contractual incompleteness that has plagued earlier incarnations of SDT or is it capable of offering a new model of more complete contractual arrangements addressing the differential needs of developing and least developed countries?

\section{Section Two - The Trade Facilitation Agreement}

The TFA aims to reduce bureaucratic barriers, speed up the movement of goods and provide a range of disciplines for the domestic administration of trade. The Agreement also seeks to implement, among other things, rules on transparency and border and customs agency cooperation. ${ }^{\text {xvi }}$ While the economic benefits predicted from the TFA have been valued at 
between US\$ 750 billion and US\$ trillion (WTO, 2015b, p. 83) its SDT provisions are of greatest interest to us. In short, under the auspices of SDT, the TFA allows developing and LDC Members to self-designate all the substantive obligations of the TFA into one of three categories. Category A obligations are those that the respective developing Members agree to implement from the date at which the Agreement enters into force (TFA, Article 15). Category B measures are those that the developing or LDC member agrees to implement but after a transition period which again is self-determined (TFA, Article 16). Category C measures are those which a developing country or LDC would require technical assistance and capacity building in order to implement (TFA, Article 14.1 (c)). Developing countries were required to notify the Committee upon the entry into force of the Agreement its Category $\mathrm{C}$ measures as well as the type of assistance required for implementation (TFA, Article 16.1 (d)). Together with relevant donor countries, developing countries then have a further year to notify arrangements entered into or maintained to facilitate implementation of category C measures (TFA, Article 16.1 (d)). Non-member donors are also to be invited at this juncture to provide information on support (TFA, Article 16.1 (d)). 18 months after the initial notification of support, donor Members and respective developing country Members are required to update on progress towards implementation and developing country Members are required to provide a definitive date for implementation of their designated Category $\mathrm{C}$ commitments (TFA, Article 16.1 (e)). A similar procedure is applicable to LDCs albeit with a more generous timescales (TFA, Article 16.2 (c) - (f)).

Where implementation capacity is lacking in respect of category $\mathrm{C}$ measures and an extension has not been granted or is not possible, developing and LDC Members are required to notify the TFA Committee. (TFA, Article 18). The Committee is directed under the TFA to convene an Expert Group of five independent experts to make a determination in respect of implementation capacity (TFA, Article 18.2). ${ }^{\mathrm{xvii}}$ In respect of LDC Members, the Expert Group may, 'as appropriate', take action to facilitate the required implementation capacity (TFA, Article 18.4).

\section{Summations}

The SDT provisions under the TFA are a significant departure from those found under other WTO Agreements (Lamp, 2015). The very structure of the TFA, with one of its three sections devoted solely to SDT, is testament to this. In particular, rigid transition periods, the cause of such ex post regret under the Uruguay Round Agreements, are nowhere to be found 
under the TFA. In the words of Neufeld (2008), the emphasis of the TFA is upon 'enhanced capabilities as opposed to mere temporary carve-outs' (283).

Drawing on what we learnt so far, the design of the TFA clearly attempts to strike a balance between ex ante commitments and ex post flexibility. Technical assistance has been provided by a range of bodies such as the WTO, UNCTAD, the World Bank and the WCO to assist developing and LDC members to conduct needs assessments in allocating their obligations to particular categories (Czapnik, 2015, p. 785; Eliason, 2015). This 'tailor-made approach' to trade law making, accompanied as it is by the provision of assistance in respect of category $\mathrm{C}$ measures has been hailed by Lamp (2015) as potentially 'signal(ling) a revival of the cooperative approach to trade lawmaking' (p. 771).

Where additional ex post flexibility is required to be exercised; that is, additional time is needed to notify or implement obligations, an Expert Group of five may be appointed (TFA, Article 18). Using the lens of contract theory, the implicit task of this group is to make a distinction between so-called efficient breach and opportunistic breach. The Trade Facilitation Committee is also tasked to take a proactive role in supporting countries to meet their implementation commitments and monitor any problems which may arise in this regard. In this vein, Cho (2014) likens the TFA to a framework agreement which leaves room for talk in that, 'implementation requires WTO members to fill in a number of unknown details' ( $p$. $710)$.

In respect of technical assistance and capacity building under Category $\mathrm{C}$ measures, this is not a binding commitment entered into by the WTO. Instead other countries - so-called 'donor' countries' as well as non-Member bodies are expected to fulfil this role. However, if countries do not receive the required assistance to implement category $\mathrm{C}$ measures, they are not required to implement them (TFA, Article 13.2). ${ }^{\text {xiii }}$ The grant of technical assistance for category $\mathrm{C}$ measures therefore operates as something of a 'pre-condition for the respective obligations of developing countries to take effect' (Lamp, 2015, p. 768). This addresses certain of the problems inherent in the grant of technical assistance under several of the Uruguay Round covered agreements whereby competence lay predominantly with the donor country to identify what assistance should be provided (Lamp, 2015, p. 768). By the same token, it is anticipated that the proactive oversight role likely to be provided by the Trade Facilitation Committee as well as the transparency obligations applicable to Donor countries 
may go some way to overcome the risk of moral hazard in the shadow of informational asymmetries.

So do the SDT provisions address the concerns regarding implementation which the contract theory analysis entered into in the previous section? It is certainly the case that the TFA is significant. It represents, 'a break from the business-as-usual model of SDT previously embraced by the WTO' (Eliason, 2015, p. 662). The ability of developing and LDC Members to unilaterally determine when to implement each of the TFA's provisions as well as the tying of implementation to the receipt of technical/ implementation assistance is unique under WTO law. Technical assistance requirements are determined by the recipient country itself on the basis of a needs based assessment. Furthermore, numerous transparency obligations exist in respect of Donor Members with the TFA Committee likely to play an important oversight role. Therefore, the verification and monitoring problems associated with so-called traditional SDT are less likely to arise under the TFA. There is, however, no obligation for so-called Donor Members to provide assistance under the TFA.

Concerns therefore remain as to the absence of a mechanism to hold Donor Members accountable for any failure to provide assistance in respect of Category $\mathrm{C}$ measures (Eliason, 2015 , p. 661). While the transparency provisions mentioned above in relation to Category $\mathrm{C}$ measures may be useful for 'moral suasion', (Finger, 2014, p. 1283) Finger, for example, has excoriated the category $\mathrm{C}$ provisions of the TFA as being akin to those of the more traditional type of SDT discussed earlier. He categorises category $\mathrm{C}$ measures as, 'another exercise in form without legal substance' (Finger, 2014, p. 1284). In a similar vein, it has been argued that the TFA 'perpetuates the pattern of asymmetrical bargains struck in previous rounds of WTO negotiations' (Wilkinson, Hannah and Scott, p. 1039) with the burdens of implementation remaining disproportionately with developing countries and LDCs (Wilkinson, Hannah and Scott, p. 1041).

The TFA clearly offers a much improved SDT offering but it is also apparent that the success or otherwise of its system of SDT depends upon the willingness of Donor Members to grant appropriate technical assistance and capacity building. However, in the absence of the provision of assistance, measures identified by developing and least developed countries as category $\mathrm{C}$ measures do not require implementation. The absence of an enforceable standard for the grant of technical assistance and capacity building, combined with the tying of obligations to the receipt of assistance serves to avoid ex post regret on the part of developing 
and LDCs. The overt rigidity of certain of the Uruguay Round covered agreements is thus avoided under the TFA and in this respect, it offers a fundamentally improved balance between ex ante obligation and ex post flexibility.

\section{Conclusions}

SDT is not a niche area of the law of the multilateral trade regime. It goes to the very heart of developing and least developed countries' legal settlement within the trade regime and is intrinsically tied to the legitimacy of the trade regime. It is part of the 'package deal' of Membership. The present study was prompted by an interest in the continuing contestation which exists on how to improve the operationalisation of SDT (see, for example, South Centre, 2017). It employed the conceptual framework provided by economic contract theory and the incomplete contract to provide a scaffold for analysing SDT to offer insights beyond those in the literature. The benefit of a contract theory analysis was that it helped us understand how SDT is incomplete and allowed us to identify and understand the consequences of such incompleteness; enriching our understanding of why vague or indeterminate SDT provisions are difficult to enforce and, by extension, why informational asymmetries present difficulties in monitoring compliance with SDT obligations. Accordingly, the contractual frame allowed us to identify the paragraph 44 mandate as a 'normal' response to the need to contractual incompleteness. It further allowed us to evaluate the TFA which we found offered a much improved approach to SDT under the WTO.

What this study was unable to do was to engage with more normative questions. In this sense, contract theory cannot answer questions of why SDT was left contractually incomplete or explore the normative underpinnings of SDT. However, normative analysis may find an entry point in a contract theory analysis of SDT. This is because contract theory helps to throw light on a fundamental dilemma within the trade regime and elsewhere in international law; how do parties ensure an efficient set of obligations given the uncertainty about the future? This tension was revealed in the design and operation of SDT with this study demonstrating how requests for flexibility should be conceived of as a fundamental component of the WTO system. Accordingly, while contract theory cannot resolve the more normative contestation which exists over SDT, it clarifies that such requests are not outside the WTO system and provides a powerful riposte to critiques in this vein. To the extent that the tension between 
commitment and flexibility is at the forefront of all contractual negotiations, the insights derived from this study are also capable of offering insights for differential treatment within international law more generally.

This study also demonstrates the utility of contract theory as a programmatic tool which can operate alongside more traditional forms of legal analysis to both warn of and remedy obligational defects. In this vein, however, we should be cognizant not to, 'treat all forms of incomplete contracts as if they were nails to be hit with the same contracting hammer: when examining and incomplete contract situation, the researcher should be conscious of the type of underlying incompleteness that his/her subject of research is affected by' (Schropp, 2009, p. 75). If SDT is a core component of the 'developmentification' of the WTO, more research is needed to fully evaluate the incompleteness at play across the full array, rather than the snap shot provided here, of SDT provisions within the WTO. 


\section{References}

Cho, S. (2014), "How the world trade community operates: norms and discourse", World Trade Review, Vol. 13 No. 4, pp. 685 -711.

Cullet, P. (1999), "Differential Treatment in International Law: Towards a New Paradigm of Inter-state Relations", European Journal of International Law, Vol. 10 No. 3, pp. 549 - 582.

Czapnik, B. (2015), "The Unique Features of the Trade Facilitation Agreement: A Revolutionary Approach to Multilateral Negotiations or the Exception Which Proves the Rule?", Journal of International Economic Law, Vol. 18 No. 4, pp. 773 - 794.

Eliason, A. (2015), “The Trade Facilitation Agreement: A New Hope for the World Trade Organization", World Trade Review, Vol. 14 No. 4, pp. 643 - 670.

Finger, J. M. (2012), "Flexibilities, Rules and Trade Remedies in the Gatt/WTO system", in Daunton, M., Narlikar, A., and Stern, R. M. (eds), The Oxford Handbook on the World Trade Organisation, Oxford University Press, Oxford, pp. 418 - 440.

Finger, J. M. (2014), “The WTO Trade Facilitation Agreement: Form without Substance Again?” Journal of World Trade, Vol. 48 No. 6, pp. 1279 - 1287.

Gantz, D. A. and Schropp, S. A. B. (2009), "Rice Age: Comment on the Panel Report in Turkey - Measures Affecting the Importation of Rice", in Horn, H. and Mavroidis, P. C. (eds), The WTO Case Law of 2006 - 2007, Cambridge University Press, Cambridge, pp. 145 $-177$.

Hoekman, B. M. and Mavroidis, P. C. (2012), “The Dark Side of the Moon: 'Completing' the WTO Contract through Adjudication”, available at http://globalgovernanceprogramme.eui.eu/wp-content/uploads/2012/11/Hoekman-MavroidisMESSERLIN-FEST FIN.pdf (accessed 17 July 2017). 
Horn, H., Maggi, G. and Staiger, R. W. (2006), "The GATT/WTO as an Incomplete Contract", available at $\mathrm{ftp}: / /$ www.cemfi.es/pdf/papers/Seminar/Giovanni06.pdf (accessed 17 July 2017).

IISD. (2003), "Special and Differential Treatment", IISD Trade and Development Brie,f available at http://www.iisd.org/pdf/2003/investment_sdc may_2003_.pdf (accessed 17 September 2017).

Lamp, N. (2015), "How Some Countries Became 'Special': Developing Countries and the Construction of Difference in Multilateral Trade Lawmaking", Vol. 18, Journal of International Economic Law, pp. 743 - 771.

McGee, J. and Steffek, J. (2016), “The Copenhagen Turn in Global Climate Governance and the Contentious History of Differentiation in International Law", Journal of Environmental Law, Vol, 28, pp. $37-63$.

Maggi, G. and Staiger, R. W. (2008), "On the Rule and Design of Dispute Settlement Procedures in International Trade Agreements”, NBER Working Paper 14067, available at http://ideas.repec.org/p/nbr/nberwo/14067.html (accessed 7 June 2017).

Mahlstein, K. and Schropp, S. A. B. (2007), “The Optimal Design of Trade Policy Flexibility in the WTO”, HEI Working Paper No 27/2007, available at http://www.hei.unige.ch/sections/ec/pdfs/Working_papers/HEIWP27-2007.pdf (accessed 7 June 2017).

Pauwelyn, J. (2006), "How Strongly Should We Protect and Enforce International Law?", Duke Law School Faculty Series, available at

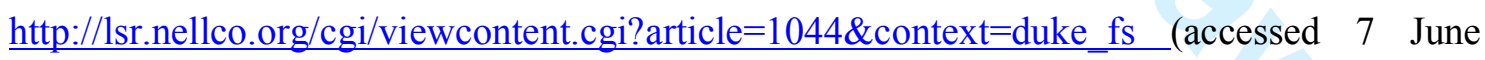
2017).

Rajamani, L. (2006), Differential Treatment in International Environmental Law, Oxford University Press, Oxford.

Rolland, S. (2012), Development at the World Trade Organization, Oxford University Press, Oxford.

Salanié, B. (1997), The Economics of Contacts: A Primer, MIT Press, Cambridge, MA. 
Scott, R. E. and Stephan, P. B. (2006), The Limits of Leviathan: Contract Theory and the Enforcement of International Law, Cambridge University Press, New York, NY.

Schropp, S. (2009), Trade Policy Flexibility and Enforcement in the WTO, Cambridge University Press, Cambridge.

Schwartz W. F. and Sykes, A. O. (2002), "The Economic Structure of Renegotiation and Dispute Resolution in the WTO/GATT System", John M. Olin Law and Economic Working Paper No. 143, available at http://www.law.uchicago.edu/files/files/143.AOS_wto_pdf (accessed 7 June 2017).

South Centre (2017),'The WTO's Special and Differential Treatment Negotiations (Paragraph 44)", SC/AN/TDP/2017/3, available at https://www.southcentre.int/wpcontent/uploads/2017/01/AN_TDP 20173 The-WTO's-Special-and-Differential-

Treatment-Negotiations-Paragraph-44_EN.pdf (accessed 7 October 2017).

Third World Network (2017), "G90 demand fruitful outcome on S\&DT at MC11", available at https://www.twn.my/title2/wto.info/2017/ti170705.htm (accessed 11 October 2017).

Trachtman, J. P. (2003), "Legal Aspects of a Poverty Agenda at the WTO: Trade Law and Global Apartheid”, Journal of International Economic Law, Vol. 6. No. 1, pp. 3 - 21.

Trachtman, J. P. (2007), "Regulatory Jurisdiction and the WTO", Journal of International Law. Vol. 10, No. 3, pp. $631-651$.

Van Aaken, A. (2009), "International Investment Law: Between Commitment and Flexibility: A Contract Theory Analysis", Journal of International Economic Law, Vol. 12 No. 2, pp. $507-538$.

Wilkinson, R., Hannah, E., and Scott, J. (2014), "The WTO in Bali: What MC9 means for the Doha Development Agenda and Why It Matters", Third World Quarterly, Vol. 35 No. 6, pp. $1032-1050$. 
Wolfe, R. (2009), "The special safeguard fiasco in the WTO: the perils of inadequate analysis and negotiation" Vol. 8 No. 4, World Trade Review, pp. 517 -544.

WTO (1995), Committee on Trade and Development, "Regulatory Obligations and Other Implications of the Uruguay Round Agreements", (13 June), WT/COMTD/W/6.

WTO (2000), Committee on Sanitary and Phytosanitary Measures 'Special and Differential Treatment - Note by the Secretariat", (5 May) G/SPS/W/105.

WTO (2001a), Ministerial Conference Fourth Session, Ministerial Decision, WT/MIN(01)/DEC/1

WTO (2001b), Ministerial Conference Fourth Session "Implementation - Related Issues and Concerns: Decision of 14 November 2001”, (20 November) WT/MIN(01)/1.

WTO (2001c), Committee on Trade and Development, "Implementation of Special and Differential Treatment Provisions in WTO Agreements and Decisions", (21 September) WT/COMTD/W/77/Rev.1.

WTO (2002a), Committee on Trade and Development, "Information on the Utilisation of Special and Differential Treatment Provisions", (7 February) WT/COMTD/W/77/Rev.1/Add.4.

WTO (2002b), Committee on Sanitary and Phytosanitary Measures, "Comments on the Canadian Proposal - Statement by Egypt at the Meeting of 7 - 8 November 2002", (15 November) G/SPS/GEN/358.

WTO (2002c), Committee on Sanitary and Phytosanitary Measures, "Enhancing Transparency of Special and Differential (S\&D) Treatment within the SPS Agreement Submission by Canada", (30 October) G/SPS/W/127.

WTO (2004), Committee on Sanitary and Phytosanitary Measures, "Procedure to Enhance Transparency of Special and Differential Treatment in Favour of Developing Country Members - Decision by the Committee - 27 October 2004", (2 November 2004) G/SPS/33. 
WTO (2007), World Trade Report 2007, World Trade Organisation, Geneva.

WTO (2009a), World Trade Report 2009, World Trade Organisation, Geneva.

WTO (2009b), Committee on Sanitary and Phytosanitary Measures, "Procedure to Enhanced the Transparency of Special and Differential Treatment in favour of Developing Countries Decision by the Committee - Revision”, (18 December 2009) G/SPS/33/Rev.1.

WTO (2013), "Monitoring Mechanism on Special and Differential Treatment - Ministerial Decision of 7 December 2013", WT/MIN(13)/45, WT/L/920.

WTO (2015a), Committee on Trade and Development, "Note on the Meeting of 24 June 2015, Reconvened on 16 September 2015”, (4 December) TN/CTD/M/15.

WTO (2015b), World Trade Report 2015, World Trade Organisation, Geneva.

WTO (2016), Committee on Trade and Development, "Special and Differential Treatment Provisions in WTO Agreements and Decisions - Note by the Secretariat", (22 September) $\mathrm{WT} / \mathrm{COMTD} / \mathrm{W} / 219$.

WTO, (2017) Ccommittee on Trade and Development - Sixth dedicated session on the monitoring mechanism on special and differential treatment, "Note on the meeting of 15 November 2016", (15 November 2016) WT/COMTD/MMSDT/M/6.

Wu, M. (2015), "Rethinking the Temporary Breach Puzzle: A Window on the Future of International Trade Conflicts", Yale Journal of International Law, Vol. 40, pp. 95 - 155.

\footnotetext{
'The designation of which countries constitute developing countries is in general - though not always - based on self-selection; see The World Trade Organisation 'Development: Who are the Developing Countries? http://www.wto.org/english/tratop_e/devel_e/d1who_e.htm).

ii This tally of SDT does not include the recently entered into force WTO Agreement on Trade Facilitation and so the figure is certainly greater than 170 .
} 
iii The allocation of jurisdiction on this issue has been left incomplete or 'muddy' to encourage countries to reveal information to each other in order to bargain; (Trachtman, 2007, p. 646).

${ }^{\text {iv }}$ See comments of the representative of India, (WTO, 2015a, at para. 54).

${ }^{v}$ See comments of the representative of United States, (WTO, 2015a, at para 52)

vi See comments of the representative of Barbados, (WTO, 2015a, at para 22)

vii At the same time as the promulgation of the Doha Ministerial Declaration, Members adopted a Decision on Implementation Related Issues and Concerns; WTO, 2001b.

viii See comments of the representative of Nepal, (WTO, 2015a, para 51).

${ }^{\text {ix }}$ See also Third World Network (TWN, 2017) which provides a useful overview of a July 2017 proposal from the ACP, African Group and LDC Group (JOB/DEV/47) which, 'expressed sharp concern over the manner in which attempts to improve the existing S\&DT provisions as per the decision on implementation issues and concerns as well as on paragraph 44 of the Doha Ministerial Declaration - "which mandates to review all special and differential provisions with a view to strengthening them and making them more precise, effective, and operational" - have been jettisoned time and time again"

${ }^{x}$ See comments of the representative of the European Union, (WTO, 2015a, para 55)

${ }^{x i}$ Other proposals have been raised to bring about the 'effective operationalization' of Article 10.1 SPS; see $\mathrm{G} / \mathrm{SPS} / 35$ and JOB(07)/99

xii It should be noted that the 2013 Bali WTO Ministerial meeting saw Members adopt a significant Decision authorising the introduction of a Monitoring Mechanism for special and differential treatment (WTO, 2013). Unfortunately, however, the Monitoring Mechanism, while praised in numerous quarters at the time of its promulgation, has proven to be a resolute failure, an empty tool box spurned by the very Members it was designed to assist. In a recent meeting of the WTO Committee on Trade and Development, the representative of Ecuador noted that, "she wished to share some thoughts as to why the MM had not been made operational. She said that the MM did not have a negotiating mandate, and could only make recommendations. The objective of the Mechanism was to monitor the implementation of S\&D provisions that were identified to be strengthened in the context of the negotiations under paragraph 44 of the Doha Declaration" (see WTO, 2017. P. 2).

xiii In this context, see for example paragraph 10.2 of the Implementation Decision (WTO, 2001b) regarding the proposal that 'developing countries with a view to achieving legitimate development goals, such as regional growth, technology research and development funding, production diversification and development and implementation of environmentally sound methods of production as non-actionable subsidies' and tiret 40 of the compendium on outstanding implementation Issues such that in relation to TRIMS, 'Specific provisions shall be included in the Agreement to provide developing countries the necessary flexibility to implement development policies (intended to address, among others, social, regional, economic, and technological concerns) that may help reduce the disparities they face vis-à-vis developed countries.'

${ }^{\text {xiv }}$ For a summary of recent proposals from the ACP, African Group and LDCs for additional flexibilities in areas such as TRIMS, see TWN (2017).

${ }^{x v}$ Indeed, according to the representative of Japan, 'Finding realistic solutions to [SDT] was a tough challenge because some of the proposed solutions could undermine the basic concepts of the WTO,' (WTO, 2015a, para 14)

xvi For a useful summary of the TFA, see WTO, 'The Trade Facilitation Agreement: An Overview' https://www.wto.org/english/tratop e/tradfa e/tradfatheagreement e.htm (accessed 22 June 2017)

xvii In respect of Article 18.2 TFA - note the operative word 'shall' in the direction for the Committee to establish an Expert Group

xviii The relevant provision directs that, "Where a developing or least-developed country Member continues to lack the necessary capacity, implementation of the provision(s) concerned will not be required until implementation capacity has been acquired." 


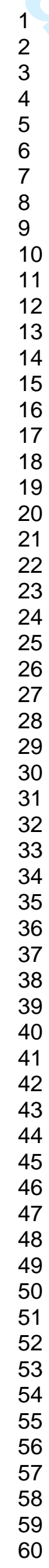

